\title{
Canonizar a un santo medieval en la Roma de la Contrarreforma: Isidro Labrador, patrón de Madrid
}

The canonization of a medieval saint in Counter-Reformation Rome: Isidore the Farmer, Madrid's patron saint

María José del Río BARREDO

Universidad Autónoma de Madrid

https://orcid.org/0001-5321-5820

mjose.delrio@uam.es

\begin{abstract}
This article focuses on the canonization process of Madrid's patron saint, san Isidro Labrador, in the post-Tridentine context of the city's transformation into the permanent seat of the Court. The first part of the article deals with the difficulties posed by the local worship of the incorrupt body of this farmer who had died centuries before and was considered a saint, but lacked formal ecclesiastical recognition. The second part analyzes Spanish diplomatic correspondence during the years that the process lasted. While St Isidore's status as a local and well-established saint was decisive, the correspondence reveals Spain's attempt to directly achieve the canonization of a figure who was now the patron not only of the Villa (town) but also of the Corte (court).
\end{abstract}

Keywords: canonization, local saint, relics, Madrid, Rome, Counter-Reformation.
Resumen: En el contexto del Madrid postridentino convertido en sede permanente de la Corte, este artículo se centra en los rasgos de san Isidro como santo local y antiguo, decisivos para el desarrollo y resultado de su proceso de canonización. La primera parte aborda las dificultades iniciales planteadas por el culto local del cuerpo incorrupto de un labrador fallecido hacía siglos y tenido por santo, pero carente de autorización eclesiástica formal. La segunda analiza la correspondencia diplomática española durante los años que duró el proceso y destaca la pretensión de alcanzar directamente la canonización del que ya era patrón no sólo de la Villa sino también de la Corte.

Palabras clave: canonización, santo local, reliquia, Madrid, Roma, Contrarreforma.

La canonización de cinco santos al mismo tiempo, cuatro de ellos españoles, en 1622 ha sido a menudo interpretada como la máxima expresión del triunfo de la monarquía española en Roma. Algunos estudios recientes han visto, sin embargo, el asunto de forma más matizada, obligando a considerar que los promotores de los dos santos jesuitas, Ignacio de Loyola y Francisco Javier, y de la carmelita Teresa de Jesús fueron órdenes religiosas de alcance internacional y otros soberanos, además de los reyes de España; Isidro Labrador fue el único 
vinculado exclusivamente a la monarquía hispánica y, de forma más específica, con su capital, Madrid. De hecho, las decoraciones del escenario preparado para la proclamación conjunta, que financió el ayuntamiento madrileño, estuvieron exclusivamente dedicadas a ensalzar la vida, virtudes y milagros de San Isidro; un gran lienzo que representaba la curación de Felipe III gracias a la intercesión del santo presidía sobre el trono papal, que estaba coronado por las armas de Gregorio XV, el rey de España y la Villa de Madrid. La resolución de la causa de san Isidro en primer lugar y la urgencia impuesta por el pontífice para que el teatro de san Pedro estuviera concluido antes de decidir las otras cuatro canonizaciones fueron las circunstancias inmediatas que justificaron esta sorprendente situación, aunque, por sí solas, no explican si hubo razones de mayor envergadura para que un santo laico y de influencia apenas local, que se desviaba sustancialmente del prototipo de santo de la contrarreforma, sobresaliera por encima de cuatro luminarias de Iglesia católica ${ }^{1}$.

Sobre la base de los trabajos previos que he dedicado a san Isidro $^{2}$, en este artículo pretendo explorar los aspectos más peculiares de su causa de canonización con el objetivo de entender mejor su éxito sorprendente en la corte romana. Parto de la consideración de que, además de su condición de laico, lo que le caracterizó principalmente es que se trataba de un santo antiguo y local: mientras que los otros santos canonizados en 1622 extendieron sus fundaciones y labor misionera en amplios territorios y fallecieron apenas unas décadas antes de que se iniciaran sus causas respectivas, el madrileño había muerto varios siglos atrás y era, según la tradición, venerado desde entonces en el entorno de Madrid y su

1 Peter BURKe, How to be a Counter-Reformation saint?, en su The historical anthropology of early modern Italy. Essays on perception and communication, Cambridge, 1987, pp. 48-62. Thomas DANDELET, «Celestiali eroi» e lo «splendor d'Iberia». La canonizzazione dei santi spagnoli a Roma in età moderna, en Giovanna FIUME (ed.), Il santo patrono e la città. San Benedetto il Moro: culti, devozioni, strategie di età moderna, Venecia, 2000, pp. 183-198. Alessandra ANSELMI, Roma celebra la monarchia spagnola: il teatro per la canonizazione di Isidoro Agricola, Ignazio di Loyola, Francesco Saverio, Teresa di Gesù e Filippo Neri (1622), en José Luís COLOMER (ed.), Arte y diplomacia de la Monarquía Hispánica en el siglo XVIII, Madrid, 2003, pp. 221-246. Miguel GOTOR, Le canonizzazioni dei santi spagnoli nella Roma barocca, en Carlos HERNANDO (coord.) Roma y España, un crisol de la cultura europea en la Edad Moderna, Madrid, 2007, t. 2, pp. 621-639. Clare COPELAND, Spanish Saints in Counter-Reformation Italy, en Piers BAKER-BATES y Miles PATTENDEN (eds.), The Spanish Presence in Sixteenth-Century Italy: Images of Iberia, Farnham, 2015, pp. 102-123 (111-112).

2 María José DEL Río BARREDO, Literatura y ritual en la creación de una identidad urbana: Isidro, patrón de Madrid, en Edad de Oro, XVII (1998), pp. 149-168 y Agiografia e cronaca di una capitale incerta (Madrid e Isidro Labrador, 1590-1620), en G. FIUME (ed.), op. cit, pp. 45-67, incorporado con leves variantes como capítulo tercero de Madrid, Urbs regia. La capital ceremonial de la Monarquía Católica, Madrid, 2000. 
comarca. En consecuencia, la primera parte de este estudio se ocupa de las tensiones y dificultades que generó el culto local del cuerpo incorrupto de Isidro, un labrador tenido por santo en la zona, pero que no había sido reconocido como tal por las autoridades eclesiásticas relevantes. Aunque se defendió que había sido canonizado al modo antiguo con la característica elevatio corporis y traslatio al interior de una iglesia, esta idea resultó difícil de conciliar con las exigencias de la Iglesia postridentina y, en particular, con los procedimientos de la primera etapa de actuación de la Congregación de Ritos. La relectura desde esta perspectiva de fuentes conocidas permite contextualizar las primeras propuestas -fallidas- de canonización, que se produjeron inmediatamente después del establecimiento de la corte de Felipe II en Madrid.

El proceso de canonización propiamente lo abordo en la segunda parte, a través de una fuente infrautilizada: la correspondencia diplomática española relativa a la causa de san Isidro, que abarca desde 1593 a 1622. En su mayoría son cartas de postulación enviadas por los reyes de España para conseguir que la curia romana sancionara su culto, incorporándolo al catálogo de los santos de la Iglesia. Al no existir todavía un procedimiento particular para las causas basadas en el culto inmemorial, como sucedería pocas décadas más tarde, las negociaciones fueron tan complejas como en cualquier otro caso. Las cartas dan cuenta detallada de ello y de la intervención de interlocutores con diversos intereses, no siempre estrictamente vinculados a la definición de la santidad.

Para analizarlas he tomado en consideración, además, los significados fluctuantes atribuidos a Isidro en una época en la que las identidades cambiantes de las comunidades locales y nacionales se articularon a menudo en torno a los santos «naturales» o nativos de un territorio. La transformación del santo madrileño desde protector de la Villa a patrón también de la Corte se desprende claramente de una correspondencia cuya cronología coincide con la consolidación de Madrid como capital y, como veremos, resulta crucial para explicar su éxito rotundo en las celebraciones romanas de 1622. Más allá de eso, el estudio de las complejidades de la causa de canonización del santo madrileño revela lo mucho que queda por hacer en el estudio de la santidad hispana de la Edad Moderna, rica en figuras principales de la Reforma Católica, pero también repleta de antiguas devociones locales no autorizadas que trataron de responder a las nuevas exigencias de la Iglesia romana ${ }^{3}$.

3 Mi trabajo debe mucho a la inspiración de los importantes estudios de William A. CHRISTIAN, Religiosidad local en la España de Felipe II, San Sebastián, 1991 y Simon DiTCHFIELD, Liturgy, Sanctity and History in Tridentine Italy: Pietro Maria Campi and the preservation of the particular, 


\section{UN «SANTO ANTIGUO» EN LA ESPAÑA POSTRIDENTINA}

El punto de arranque de los estudios dedicados al culto de san Isidro es invariablemente el relato de su vida y milagros, tal como se recogía en un manuscrito latino, presumiblemente redactado en el siglo XIII por un diácono llamado Juan y con adiciones fechadas en el XV. El «Códice de Diácono» narra la historia de un campesino que había vivido en Madrid con reputación de santo, cuyo cuerpo incorrupto se conservaba en la iglesia parroquial de san Andrés. La fecha de su muerte no se indica, pero sí que había tenido lugar cuarenta años antes de que su cadáver fuera exhumado y llevado desde el cementerio donde inicialmente había sido enterrado hasta una capilla situada en el interior de la iglesia, «al lado de los altares de los Santos Apóstoles». Con particular minucia se describe la elevación del cuerpo (elevatio corporis) desde el suelo y su traslado (traslatio), uno de los milagros más prodigiosos y capaces de demostrar su santidad. Las señales eran inconfundibles: el mismo Isidro había pedido ser desenterrado y trasladado, apareciendo en sueños a dos personas; su cuerpo se encontró en perfecto estado y «desprendiendo un suave olor de incienso»; finalmente, las campanas estuvieron repicando sin que nadie las tocara mientras duró el traslado. El autor del manuscrito subrayaba que tales signos fueron considerados por los contemporáneos del suceso y las generaciones sucesivas como expresión de la mano de Dios y que así «otorgaron a Isidro el título de Santo, con absoluta convicción, sin la autoridad eclesiástica ${ }^{4}$.

El relato hagiográfico proporcionó al cuerpo incorrupto conservado en san Andrés una identidad específica y definida con rasgos propios de la santidad medieval. Isidro se presentaba como un taumaturgo al que se recurría para recupe-

Cambridge, 1995 y Il mondo della Riforma e della Controriforma, en AA.VV., Storia della santità nel cristianesimo occidentale, Roma, 2005, pp. 261-329. Sobre la santidad en la España Moderna, Eliseo SERRANO MARTíN, Santidad y patronazgo en el mundo hispánico de la Edad Moderna, en Studia Historica, Historia Moderna, 40/1 (2018), pp. 75-123; Inmaculada ARIAS DE SAAVEDRA, Esther JIMÉNEZ PABlo y Miguel LóPEZ-GUADALUPe, Subir a los altares. Modelos de santidad en la monarquía bispánica (siglos XVI-XVIII), Granada, 2018. Marcello Bruzzo ha contribuido de muchas formas a la realización de este artículo y se lo agradezco infinitamente. La investigación se inscribe en el proyecto PGC2018-094150-B-C22.

4 Las citas proceden de la traducción y edición de Fidel FITA, Madrid desde el año 1235 hasta el de 1275. Ilustraciones y texto de la Vida de San Isidro por Fuan Diácono, en Boletín de la Real Academia de la Historia, IX (1886), p. 122. Un comentario más extenso en Zacarías GARCía VILLADA, San Isidro labrador en la bistoria y en la literatura, Madrid, 1922 y Matilde FERNÁNDEZ MONTES, San Isidro, de labrador medieval a patrón renacentista y barroco de la Villa y Corte, en Revista de dialectología y tradiciones populares, tomo LVI (2001), pp. 41-95. 
rar la salud -a menudo gracias al contacto con su cuerpo, vestidos y tierra de su sepulcro- y para conseguir que lloviera cuando el campo lo necesitaba. Aunque sus milagros en vida subrayaban las virtudes de la piedad y la caridad, los que le fueron atribuidos después de muerto se repartían entre curaciones, eficaces rogativas y castigos a quienes dudaban de su santidad o trataban de apropiarse indebidamente de sus reliquias. Con el tiempo, a los prodigios recogidos por Diácono, se unieron otros centrados en las virtudes curativas del agua de una fuente situada en las afueras de Madrid y sobre la cual construyó una ermita la cofradía de san Isidro, existente desde al menos finales del siglo XV. Tales milagros y las visitas piadosas a la ermita son una constante en los procesos informativos realizados a finales del siglo XVI con vistas a su canonización ${ }^{5}$.

La ermita, el cuerpo incorrupto y el manuscrito de Diácono constituyen los tres elementos del culto local de Isidro que el primer cronista de Madrid, Juan López de Hoyos, destacó en un comentario sobre el escudo de la Villa publicado en 1569. El humanista situaba la vida del santo en el siglo XI, asociándolo así a la recuperación de Madrid de manos musulmanas, aunque también lamentaba que «por culpa del Pueblo y sus Ciudadanos, con ser el mismo santo de Madrid, no está canonizado ${ }^{6}$. La frustración que denota este comentario pone en evidencia que las bases previamente aceptadas de la santidad de Isidro habían dejado de ser suficientes. La nueva perspectiva estuvo influida por dos importantes acontecimientos recientes: el establecimiento de la corte de Felipe II en Madrid y la conclusión del Concilio de Trento. La presencia de la corte puso al santo local bajo la mira de un número mayor de devotos potenciales, algunos de los cuales podían ser más exigentes respecto a la legitimidad de su culto, mientras que Trento alertó sobre los posibles abusos en el culto dado a los santos, en particular a

5 Ver, entre muchos otros, los testimonios de la Información de la vida y milagros del bienaventurado san Isidro Labrador de Madrid, 1598, ff. 25, 30-31, 50-52, 59, 63, 117-118, 122-125, 131, en MADRID. ARCHIVO DE VILLA, Secretaría, 2-285-1. Una versión resumida de los milagros organizados por temas en MADRID. BIBLIOTECA NACIONAL [en adelante BNE], VE 201-117 Relación en suma sacada de la información que se ha hecho de la vida y milagros de S. Isidro, labrador en la Villa de Madrid [1598]

6 Juan LóPEZ DE HoYos, Historia y relación verdadera de la enfermedad, felicísimo tránsito y suntuosas exequias fúnebres de la serenísima reina de España doña Isabel de Valois, Madrid, 1569, sección final sin paginar. Las fechas de la vida y muerte de san Isidro varían sustancialmente según los autores. $\mathrm{Al}$ incluirlo en su compilación, Joan Basilio SANCTORO, Segundo volumen de la bagiografía y vidas de los santos del Nuevo Testamento, Bilbao, 1580, p. 469, afirmó que había vivido entre 1232 y 1275. Juan de MARIETA, OP, Historia eclesiástica de todos los santos de España, Cuenca, 1596, pp. 154v$156 \mathrm{v}$, sitúa su muerte en 1170 y su traslado en 1210 , de modo que su primer milagro fuera colaborar en la victoria de las Navas de Tolosa de 1212. 
sus imágenes y reliquias. Ambos factores proporcionan el trasfondo polémico en el que se desenvolvieron los primeros intentos de obtención de una autorización eclesiástica del culto de Isidro.

De las molestias que el ayuntamiento de Madrid se tomó para regularizar la situación del santo local dejan constancia varios acuerdos municipales: en diciembre de 1562 los ediles municipales rogaron al nuevo embajador del rey de España ante la Santa Sede, que les ayudara a conseguir la canonización de Isidro y siete meses después acordaron escribir sobre el mismo asunto a las autoridades del arzobispado de Toledo y otras personas competentes. Aunque tenían una idea aproximada sobre los hilos que debían mover, los resultados de estas primeras gestiones quedaron muy lejos de sus expectativas.

El Comendador mayor de León llevaba ya el encargo de ocuparse en Roma de la canonización de fray Diego de Alcalá, un franciscano fallecido el siglo anterior en la ciudad vecina y a cuya reliquia se atribuía la curación del príncipe don Carlos, que había sufrido un grave accidente mientras estaba allí de visita con su padre. Las autoridades madrileñas trataron de aprovechar la ocasión, considerando que sería ventajoso tratar los dos casos a la vez: «en efecto, ha de costar poco más canonizar el cuerpo de san Esidre, habiéndose de canonizar el del Santo fray Diego» ${ }^{7}$. Es posible que les moviera no sólo el ahorro, sino también cierto afán de emulación con Alcalá, pues el énfasis que pusieron en «canonizar el cuerpo» de los santos remitía al prestigio que las ciudades otorgaban a la posesión de sus reliquias. El nuevo papel de Madrid como residencia de la Corte obligaba como mínimo a igualarse con la villa universitaria. Sin embargo, nada indica que Felipe II respaldara la demanda municipal. Los esfuerzos del soberano estaban entonces centrados en la causa de fray Diego, que, en todo caso, tampoco prosperó hasta dos décadas más tarde, cuando los intereses del rey de España y los del pontífice coincidieron en la lucha contra Inglaterra ${ }^{8}$. En esos años, el soberano apoyaba asimismo las causas de Raimundo de Peñafort, Luis Bertrán y Juan de Sahagún y la promoción del Labrador quedó relegada hasta 1593.

La respuesta desde el arzobispado de Toledo a la petición formulada en 1563 por el ayuntamiento de Madrid no se hizo esperar tanto, pero resultó muy dis-

7 Una transcripción de los libros de acuerdos, 23 de diciembre de 1562 y 19 de julio de 1563 en Leonor ZOZAYA MONTEs, Pesquisas documentales para narrar la bistoria de San Isidro. Gestiones para una canonización iniciada en 1562, en Prisma social, 4 (junio 2010), pp. 7-9.

8 Para el contexto político de la canonización de san Diego ver Andrew VillaLON, San Diego de Alcala and the Politics of Saint-Making in Counter-Reformation Europe, en The Catholic Historical Review, 83, 4 (1997), pp. 691-715. 
tinta de la que se esperaba. En 1567, las autoridades episcopales, encabezadas por el gobernador de la archidiócesis, don Gómez Tello de Girón, visitaron la tumba del santo en la iglesia de san Andrés, abrieron el arca donde estaba su cuerpo, lo inspeccionaron y encargaron que se limpiara todo antes de cerrarla de nuevo. Durante la operación no se abrieron las puertas de la iglesia al público, porque, como anotaron en el libro de visitas no se trataba de un santo canonizado. Poco después, el canónigo de Alcalá y visitador eclesiástico, Jorge Gerzón ordenó que no se volviera a sacar el cuerpo de Isidro a la pública veneración, ni para tomar parte en celebraciones, salvo expresa licencia del arzobispado, «atento a no estar canonizado» ${ }^{9}$. Una medida tan drástica no pudo menos que dar un golpe notable al culto del santo madrileño y a sus perspectivas de canonización.

Las circunstancias empezaron a ser más favorables a partir de 1584, cuando el nuevo visitador del arzobispado, el doctor Segura Dávalos, acudió a ver la reliquia y permitió que el arca permaneciera nueve días abierta sobre un altar, a la vista de todo el pueblo. El proyecto de canonización fue retomado gracias al impulso entusiasta de Domingo de Mendoza, fraile dominico del convento de Nuestra Señora de Atocha y activo promotor de tradiciones piadosas en el Madrid de la época. El 11 de septiembre de 1588 se dirigió al ayuntamiento, solicitando que se renovaran los esfuerzos para conseguir el anhelado reconocimiento papal de la santidad de Isidro; con ese fin, ponía a su disposición un memorial donde se indicaba el procedimiento a seguir y él mismo se ofrecía para buscar la documentación relevante en el archivo municipal. Para Mendoza era fundamental la elaboración de una vida del santo actualizada y hay indicios de que compiló materiales con ese fin, aunque sus resultados más eficaces procedieron de plumas de autores consagrados a los que él estimuló. Al renombrado autor de vidas de santos, Alonso de Villegas, al poeta y dramaturgo, Lope de Vega, y al calificador inquisitorial y apologista de la fe católica, fray Jaime Bleda (O.P.) les prestó su copia del Códice y les dio indicaciones para que ampliaran el relato hagiográfico con tradiciones orales y escritas más recientes, incluidas las contenidas en las probanzas de la canonización, en cuya recogida él mismo colaboró. Los tres escritores reflexionaron sobre lo que significaba canonizar a un santo que desde hacía siglos era ya estimado como tal.

9 El acta de las visitas episcopales se recoge al final de la copia del manuscrito de Diácono realizada por Pero Gómez de Cuenca a petición de fray Domingo de Mendoza en 1595, Historia Sancti Isidori Agricola ac beatae Mariae de la Cabeza unicae eius uxoris madritensium toletanae diocesis, en BNE, ms. 17649. La cita procede del f. 38v. Sobre Jorge Genzor, Antonio MARCHAMALO SÁNCHEZ, La Iglesia Magistral de Alcalá de Henares en la universidad cisneriana, 1499-1831, Universidad Complutense de Madrid, 2017, pp. 248 y 622. 
En el libro de Alonso de Villegas, que la cofradía de san Isidro costeó en 1592, se seguía de cerca el texto medieval, aunque con la incorporación de detalles, en parte procedentes de los resúmenes incluidos en la obra de otros expertos hagiógrafos. Lo mismo que el sacerdote Juan Basilio Sanctoro, Villegas localizó en Carabanchel una de las iglesias que, según Diácono, Isidro visitaba a diario. Además, lo relacionó estrechamente con la Virgen de Nuestra Señora de Atocha y dio un nombre específico a la mujer de Isidro, que Diácono mencionaba de paso, vinculándola con varios lugares de la comarca madrileña, específicamente Talamanca y la ermita de Nuestra Señora de la Cabeza, donde aseguraba que estaba enterrada. Al concluir su breve relato, el autor toledano animaba al ayuntamiento de Madrid a proseguir la canonización del santo local, señalando de pasada que «el no estar canonizado ha sido por culpa de los pasados, que en esto han tenido descuido». Al mismo tiempo afirmaba que la preservación del cuerpo del santo, su elevación desde la zona de los sepulcros comunes y el traslado al interior de un santuario «era antiguamente canonizar a uno por santo ${ }^{10}$. Comparando el caso con el de otros santos españoles cuyas vidas había escrito, insinuaba que se había hecho de ese modo y que seguramente habían contado con la autorización del prelado que previamente había realizado investigaciones sobre su vida y milagros. Si bien admitía que las canonizaciones eran prerrogativa exclusiva del pontífice, intentaba no dejar dudas sobre la certidumbre de la santidad presumida de Isidro: la confirmaban los exvotos de cera y las pinturas que había en su tumba, la concesión de una indulgencia papal de 1584 para quienes visitaran su altar y ermita y el mismo nombre que todos le daban de «santo».

A partir del Códice de Diácono y considerando las novedades incorporadas por Villegas, Lope de Vega compuso en la década de 1590 una comedia y un extenso poema épico dedicado a san Isidro. Con la mayor libertad que le permitía la literatura, incidía en la relación del santo madrileño con la Virgen de Atocha, incluía escenas de la vida matrimonial de Isidro y María de la Cabeza en Madrid y su comarca y difundía nuevos prodigios, algunos ya apuntados por Villegas, como el de la fuente que el santo había hecho brotar con su aguijada, el de María atravesando sobre un manto las aguas el Jarama y el de la aparición del Labrador al vencedor de la batalla de las Navas de Tolosa. Tanto en la comedia como en el poema, Lope recreaba la muerte de Isidro y la posterior exhumación de su cuerpo. En la pieza teatral incorporó una escena en la que se descubría una cortina y

10 Las dos citas proceden de Alonso De VILlegas, Vida de Isidro Labrador, Madrid, 1592, f. 20v. Una edición de la obra a cargo de Chad LEAHY, en Lemir, 19 (2015), pp. 898-930. 
aparecía el cuerpo del santo sobre un altar y con la cabeza bien alta para que los espectadores pudieran verlo bien, mientras un personaje explicaba: $\ll_{i} E l$ estar de esta suerte levantado,/ es en la edad del siglo en que le han puesto,/como haberle Madrid canonizado!» ${ }^{11}$. En el poema Isidro, este tema ocupaba prácticamente todo el último canto, que comenzaba con la recreación de la muerte piadosa del santo en presencia de seres celestiales y el ascenso de su alma al cielo, donde se encontraba con la jerarquía de santos. Siguiendo a Diácono, Lope describía la elevación y traslado del cuerpo, añadiendo que en ese momento todos los presentes le proclamaron santo a voces. Como Villegas, a quien citaba, declaraba que la elevación era el modo de canonizar en la España medieval, aunque después matizaba que eso permitía únicamente venerar al santo hasta que el papa por su potestad exclusiva le canonizara. Publicado en 1599, el poema daba cuenta de que la Villa de Madrid trabajaba en ello de la mano de fray Domingo de Mendoza, a quien presentaba como el responsable de recoger las informaciones sobre los milagros que harían a Isidro indudable merecedor de la corona celestial ${ }^{12}$. Lope sacó de nuevo el tema en su relación de las fiestas madrileñas de canonización, donde se refería brevemente a las discrepancias entre quienes habían apoyado el proceso y los «muchos» que habían creído innecesario buscar el reconocimiento romano por considerar que Isidro había sido santificado al modo antiguo. El escritor aclaraba que los signos de santidad, como la elevación del sepulcro, la dedicación de capillas y altares y las imágenes del personaje con corona y resplandores, habían bastado para convencer a todos en el pasado, cuando la gente «creía mucho y preguntaba poco» ${ }^{13}$.

Despejar las dudas surgidas durante el largo, y para algunos incomprensiblemente complejo, camino de Isidro a los altares fue uno de los objetivos principales de la Vida y milagros del glorioso San Isidro el Labrador, abogado y patrón de la Real Villa de Madrid, por Juan Diácono, arcediano de la misma Villa, con adiciones por el padre presentado faime Bleda (1622). Como declaraba su autor, el fraile dominico de Valencia mejor conocido por sus escritos apologéticos contra los moriscos, esta obra en dos tomos pretendía extender la devoción del santo madrileño y eso

11 Lope De Vega, Comedia famosa de san Isidro Labrador de Madrid, en Obras de Lope de Vega, tomo 10, Comedias de vidas de santos, BAE, 178, Madrid, 1965, p. 441. Sigo la datación que argumenta Noël Salomon, Sur la date de San Isidro labrador de Madrid, «comedia» de Lope de Vega, en Bulletin bispanique, 63 (1961), pp. 5-27.

12 LOPE DE VEGA, Isidro. Poema castellano, Madrid, 1599, ff. 239r-252v.

13 LOPE DE VEGA, Relación de las fiestas que la insigne Villa de Madrid hizo en la canonización de su bienaventurado bijo, y patrón San Isidro, Madrid, 1622, sin paginar. 
justificaba la amplitud de los comentarios teológicos y la incorporación de un resumen de todos y cada uno de los milagros recogidos en los procesos de canonización. Al reescribir la vida de Isidro a partir de Diácono, Jaime Bleda se definía como historiador dispuesto a sacar a la luz todos los documentos pertinentes y a utilizar conjeturas cuando éstos faltaran. Trataba de distinguir su labor de la de un jurista, explicando que no aspiraba a probar nada, pero a la vez afirmaba que pretendía demostrar toda la verdad sobre el santo madrileño, a pesar de que muchas fueran «verdades enterradas desde hacía mucho tiempo», porque quería responder a quienes habían puesto «las cosas en tela de juicio y disputa» ${ }^{14}$. En efecto, los tonos más polémicos y el recurso a los juristas están muy presentes en las abundantes y dispersas páginas dedicadas a la canonización de Isidro.

Los tiros más directos de Bleda se dirigieron a Jorge Genzón, el visitador del arzobispado de Toledo que había impedido el culto público del cuerpo de Isidro durante más de una década. El dominico reconocía su autoridad para exigir que sólo se hiciera con licencia episcopal previa, pero cuestionaba la oportunidad de haber desvelado que el Labrador no estaba canonizado. Dando por sentado que se habían aplicado los decretos canónicos relativos a las reliquias, criticaba también su aplicación al caso. Afirmaba que la prohibición por el cuarto concilio de Letrán de sacar los restos de santos de sus relicarios y la exigencia de autorización eclesiástica para la veneración de nuevas reliquias, se refería a restos anónimos, utilizados con fines venales o en aquellos casos en que había riesgo de que los huesos se deshicieran. Pero ese no era el caso del cuerpo de Isidro, que -subrayaba- se había conservado desde hacía siglos «entero, sano y oloroso» y, como tal, constituía un testimonio seguro de la resurrección de los cuerpos al final de los tiempos, además de manifestar el estado de gloria que disfrutaban los amigos de Dios. En consecuencia, su exhibición era necesaria para estimular la veneración en los fieles y permitirles participar de la gracia del santo, además de refutar la aversión de los protestantes hacia las reliquias. Palabra por palabra,

14 Jaime BLEDA, Vida y milagros del glorioso San Isidro el Labrador, bijo, abogado y patrón de la Real Villa de Madrid, Madrid, 1622, tomo 1, prólogo sin paginar. Trata el tema de la canonización en el tomo 1, capítulos 4, 5, 6, 28-30 y 33 y en el tomo 2, capítulos 7-10. Alude al padre Mendoza en p. 282. En su reelaboración de la vida de Isidro primó el objetivo de extender la devoción por encima del deseo de ofrecer una historia verdadera, razón por la que esta obra suele ser denostada, aunque se utiliza más de lo que se reconoce. Como historiador se mostraba escéptico respecto a la fiabilidad de algunos cronicones de la época, como el de Dextro, al que alude, aunque eso no le impedía utilizarlos. Sobre la escritura de la historia sagrada en la España de la época y el papel central de la santidad local en ella, Katrina B. OLDS, Forging the Past. Invented Histories in Counter-Reformation Spain, New Haven-London, 2015. 
reproducía varias páginas del reciente tratado publicado por el obispo Sancho Dávila y Toledo, uno de los más fervientes promotores del culto de las reliquias en la España de la época ${ }^{15}$. Citándolo, indirectamente declaraba que el rigor de las autoridades toledanas no era compartido por otros prelados. Bleda más bien presentaba el gesto de Genzón como una arbitrariedad e incoherencia, teniendo en cuenta que había realizado otra visita a puerta cerrada en 1576, en la que, junto a un reducido grupo de cortesanos, disfrutó a su antojo de las reliquias del santo.

Si restringir las posibilidades de que el pueblo aumentara su devoción al santo con la vista de su cuerpo era para Bleda una medida deplorable, negar que las reliquias de Isidro fueran las de un santo canonizado resultaba todavía más grave porque incrementaba la desconfianza y tal vez la incredulidad. De forma indirecta expresaba esta idea al recordar enfáticamente que los santos castigaban a quienes no creían en ellos y que Isidro no se había quedado corto en ese aspecto, como demostraban sus milagros; entre ellos estaba el de un tal Giuseppe, criado del nuncio, al que una noche se apareció el santo y le maltrató por haber negado que pudiera realizar curaciones milagrosas no estando canonizado ${ }^{16}$.

Aclarar a los lectores cuál había sido realmente la situación del Labrador antes de 1622 era una de las principales preocupaciones de Bleda. Admitía su exclusión de la lista de santos recogida en el tratado de referencia de Angelo Rocca, De canonizatione sanctorum commentarius (1601), pero explicaba que allí sólo se incluían los canonizados por el papa y el santo madrileño lo había sido al «modo antiguo», esto es, a través de la elevación y el traslado de su sepulcro. Apelaba al relato de Diácono y a la presencia del cuerpo incorrupto en un lugar privilegiado de la iglesia de san Andrés, además de recurrir a un argumento circular para defender que el traslado se había realizado necesariamente con permiso episcopal: aunque no se conservaban documentos que lo avalaran, así se hacía siempre en el pasado; más aún, cabía la posibilidad de que en algún momento se hubiera solicitado licencia al papa, «a la Sede Apostólica sin duda acudieron antiguamente los arzobispos de Toledo por licencia» ${ }^{17}$. La única razón por la que en tiempos recientes se había buscado el reconocimiento papal con una «canonización solemne» era para acallar los escrúpulos de algunos. Con evidente

15 Bleda, op. cit., pp. 258ss. Sancho Dávila Y TOLEDO, De la veneracion que se debe a los cuerpos de los santos y a sus reliquias, Madrid, 1611, pp. 147-149. Sobre el oblispo de Jaén, Katie HaRRIS, « $A$ known boly body, with an inscription and a name»: Bishop Sancho Dávila y Toledo and the Creation of St. Vitalis, en Archiv für Reformationsgeschichte, 104 (2013), pp. 245-271.

16 BLEDA, op. cit., t. 2, p. 127.

17 Ibid., t. 1, p. 42. 
tensión, el dominico trataba de conciliar la canonización al modo antiguo con la reserva pontificia que, como él mismo recordaba, había sido establecida en el breve Audivimus de Alejandro XIII e incorporada a las decretales en 1234. A partir de entonces no se podía ignorar que sólo el papa tenía competencias universales para incluir a un candidato en el catálogo de los santos y obligar así a que toda la Iglesia le diera culto.

Las dificultades de Bleda para explicar la situación de san Isidro se entienden mejor recordando brevemente lo que en la práctica supuso la reserva papal en los siglos finales de la Edad Media. De acuerdo con el estudio clásico de André Vauchez, aunque la fórmula de la traslatio en presencia o con autoridad de un prelado perdió validez jurídica, eso no significó su abolición, ni mucho menos que la curia romana se empeñara en hacer efectiva la exclusividad papal en todos los casos. Los obispos continuaron apoyando la práctica tradicional a petición de las comunidades locales o por iniciativa propia y también siguieron encargados de velar por otros aspectos de la disciplina relacionada con el culto de los santos, como la honra de las reliquias y la recogida de los milagros atribuidos a personas fallecidas en olor de santidad. Aun cuando el procedimiento de canonización papal estaba desarrollado desde el siglo XIII, el número de causas atendidas en Roma, después de una primera etapa, comenzó a decaer. Las comunidades locales no podían sostener el esfuerzo en tiempo y dinero que exigían la recogida de informaciones y, sobre todo, las negociaciones en la curia romana, por lo que solían inhibirse de solicitarlo. En Roma misma se rechazaron, además, numerosos casos desde los primeros estadios, de modo que progresaron solamente los candidatos acordes a determinados modelos de espiritualidad o los que estaban promocionados por órdenes religiosas y casas dinásticas afines a los intereses religiosos y políticos de la Sede apostólica. De ese modo, se produjo una separación cada vez mayor entre el pequeño número de canonizados a los que se rendía culto oficial y los mucho más abundantes santos con reconocimiento de las iglesias locales. Estos últimos proliferaron lejos del control de la iglesia romana, que no rehusó, sin embargo, compensarles con indulgencias, una concesión interpretada a menudo como ratificación indirecta de su culto. Nadie cuestionaba la superioridad de los santos canonizados, pero se ofrecían honras equivalentes a los que no lo estaban, porque la canonización papal se entendía con una confirmación de la local y, aunque era apreciada, no resultaba esencial ${ }^{18}$.

18 André VAUCHEZ, La sainteté en Occident aux derniers siècles du Moyen-Age, Roma, 1988, pp. 69120. 
A pesar de que después del Concilio de Trento se tendió a fortalecer la exclusividad papal con un control más férreo de los cultos locales, las concepciones tradicionales sobre la santidad se mantuvieron al menos hasta que Urbano VIII reguló los procedimientos de canonización. Por eso, sin oponerse a la prerrogativa pontificia, Jaime Bleda enumeraba las indulgencias que disfrutaba el culto de Isidro, las capillas que se le dedicaban y hasta los himnos recogidos en el códice de Diácono, que insinuaban la existencia de un oficio litúrgico propio, que decía haber sido olvidado por la negligencia de los curas y beneficiados de san Andrés. En este aspecto, señalaba, el culto del santo madrileño coincidía con otros «santos antiguos» españoles de los que tampoco había memoria precisa de canonización, pero que estaban incluidos en el Martirologio romano y, en consecuencia, eran venerados con el oficio correspondiente. Como hicieron otros autores antes que él, Bleda llamó la atención sobre las imágenes que representaban a Isidro con diadema y aureola de santo y sobre el hecho de que tradicionalmente se le conociera con ese nombre, en lugar de la categoría inferior de beato, reservada a los no canonizados. En este último punto, seguía al pie de la letra la obra del valenciano Vicente Justiano Antist (O.P.), dedicada a fray Luis Bertrán, cuyo reciente proceso de canonización había traducido Bleda al latín. Antist rechazaba el uso de los términos «beato»y «beata» por las connotaciones negativas que tenían en castellano, a diferencia del italiano y también coincidía con Bleda en su respuesta a los «escrupulosos» que criticaron las honras hechas a Bertrán después de su muerte en 1581, alegando que no estaba aún canonizado. Antist defendía la autoridad de los obispos locales para que el cuerpo de la persona fallecida en olor de santidad pudiera ser enterrado en lugar separado, se conservaran sus ropas y usaran como reliquias y tolerase la colocación de exvotos en memoria de sus milagros. Argumentaba que esas honras eran descritas en numerosas vidas de santos y que, evidentemente, ninguno había sido canonizado el mismo día de su muerte, ni sus devotos acudido a Roma «volando por el aire a pedir licencia» ${ }^{19}$.

La referencia a Antist tiene especial interés porque su libro, traducido al italiano en 1583, tuvo influencia en las discusiones sobre el culto de los llamados beatos modernos que se produjeron en la curia romana a principios del si-

19 Vicente Justiniano ANTIDST, OP, Verdadera relación de la vida y muerte del padre fray Luis Bertrán, de bienaventurada memoria, Zaragoza, 1583, p. 311. Sobre Bleda como traductor del proceso de Bertrán, Rafael BENÍTEZ SÁNCHEZ-BLANCO, La figura y la obra de fray Faime Bleda, en Rafael BENÍTEZ SÁNCHEZ-BLANCO (ed.), Tríptico de la expulsión de los moriscos. El triunfo de la razón de estado, Montpellier, 2012, capítulo 3. https://books.openedition.org/pulm/1147?lang=es 
glo XVII ${ }^{20}$. La Congregación de Ritos, establecida en 1588 para asesorar al pontífice en asuntos relacionados con el culto de los santos, facilitó la renovación de las canonizaciones, interrumpidas desde 1523 como resultado de las críticas de erasmistas y protestantes. En el procedimiento estaba ya establecida la diferencia entre el proceso ordinario, en manos de los obispos locales, y el apostólico, realizado con independencia de los resultados obtenidos en el primer momento; pero no estaba claro a qué instancias correspondía la autorización de los nuevos cultos en sus estadios iniciales. En la Congregación de Ritos se denunciaron los excesos de la veneración a personas fallecidas en olor de santidad, pero que no tenían autorización papal para ser objeto de culto. Para evitar ese tipo de situaciones y discutir si en tales casos se podía permitir alguna forma de culto se instituyó la llamada Congregación de los beatos (1602), un órgano de corta duración, pero importante como antecedente de los decretos que en tiempos de Urbano VIII fijaron los nuevos procedimientos de canonización.

A principios del siglo XVII estaba fuera de discusión la exclusividad papal en materia de santidad, pero los cardenales más flexibles, como Belarmino, defendieron que el control de las devociones más o menos privadas podían quedar bajo la responsabilidad de los obispos, en la línea de lo establecido en la última sesión de Trento. Argumentaban que una severidad excesiva no habría permitido el desarrollo del culto a los santos en el pasado, ni dejaría hacerlo en el presente. En contraste, los más rigoristas, entre los que se encontraba el auditor de la Rota Francisco Peña, abogaban por la subordinación de los obispos a las directrices del papa y el control inquisitorial de las nuevas devociones. Esta fue la línea que acabó imponiéndose para los cultos de los nuevos beatos sobre los que giraron los debates, dejando fuera los establecidos desde hacía mucho tiempo. Se mostró muy consciente de esa diferencia Jaime Bleda, que estuvo en Roma por esas fechas y que, entre sus argumentos en defensa del culto de san Isidro antes de su canonización solemne, alegó que la Iglesia en ningún momento había «derogado tan sana costumbre de honrar los santos antiguos con ninguna de las leyes que acerca de esto ha promulgado» ${ }^{21}$.

20 Para estas cuestiones me apoyo sobre todo en Miguel GoTor, I beati del Papa. Santità, Inquisizione e obbedienza in età moderna, Florencia, 2002, especialmente pp. 172-183 y 233-244. Ver también Simon DITCHFIELD, Coping with the «beati moderni»: Canonization procedure in the aftermath of the Council of Trent, en Thomas M. MCCOOG (ed.), Ite inflammate omnia. Selected historical papers from conferences beld at Loyola and Rome in 2006, Roma, 2010, pp. 413-439.

21 BLEDA, op. cit., p. 42. Sobre sus viajes a Roma, Manuel SERRANO y SANZ, Memorial de fr. Jaime Bleda, en que expone sus servicios y solicita se le conceda una pensión, en Revista de Archivos, Bibliotecas y Museos de Madrid, IV (1900), pp. 275-276 y María Antonietta VISCEGLIA, Roma papale e Spagna. Diplomatici, nobili e religiosi tra due corti, Roma, 2010, pp. 231-242. 
Pese a que los santos antiguos quedaron, efectivamente, fuera de los debates, en la práctica se vieron afectados por las críticas severas a los nuevos cultos que aún carecían de autorización papal. Tampoco quedaron al margen de las transformaciones que como resultado se introdujeron en el procedimiento de canonización en la primera década del siglo XVII. La más importante fue el establecimiento obligado del estadio intermedio de la beatificación con el que la curia respondía a las exigencias más rigurosas en materia de culto y al número creciente de solicitudes de canonización. Los cinco santos de la proclamación de 1622 estuvieron entre los primeros en ser formalmente beatificados como paso previo a su canonización. Con anterioridad, los pontífices habían otorgado permisos para celebrar el culto en el ámbito de una orden religiosa o en un territorio específico, pero a principios del siglo XVII la beatificación adquirió un carácter jurídico autónomo y se convirtió en un paso forzoso hacia la canonización, aunque sin implicar que ésta se conseguiría.

Cuando en 1619 Isidro Labrador fue beatificado, quienes apoyaban su causa tuvieron que sentirse sorprendidos, si no desencantados, porque esperaban un reconocimiento solemne que diera mayor lustre a su canonización al estilo antiguo. El libro de Bleda, escrito en parte antes de que tuviera lugar la definitiva proclamación de su santidad ${ }^{22}$, fue primera historia de un proceso que, a pesar de concluir de forma exitosa, tuvo momentos de desaliento. Y es que la causa de canonización de Isidro tuvo lugar en un periodo de transformación, en el que comenzaban a introducirse cambios de procedimiento, que sólo se completaron algunos años después. Por eso, en su importante estudio sobre la beatificación, Monseñor Veraja afirmaba que si la canonización de Isidro se hubiera tratado algunos años más tarde, se habría hecho de forma más sencilla y directa, sin necesidad de pasar por una fase intermedia ${ }^{23}$. Con los decretos promulgados por Urbano VIII en las décadas de 1620 y 1630, ningún candidato a la santidad podría

22 Evidencias internas del libro de Bleda muestran que escribió la mayor parte del primer volumen antes de que Isidro hubiera sido declarado santo, mientras que el segundo salió a la luz apenas dos meses después. Las aprobaciones y la suma del privilegio del volumen 1 están fechadas en noviembre de 1621, aunque también se incluyen dos dedicatorias de la primavera de 1622, seguramente añadidas más tarde. En el segundo volumen, que lleva una dedicatoria del autor al ayuntamiento de Madrid, fechada a 15 de mayo de 1622, el dominico describe con la inmediatez de un reportero las fases finales de la causa, sin incorporar ya sus propias reflexiones.

23 Fabijan Veraja, La beatificazione. Storia, problemi, prospettive, Roma, 1983, p. 58, nota 106. Desde una perspectiva más continuista, cuestiona ese punto de vista Giovanni PAPA, Le cause di canonizzazione nel primo periodo della Congregazione dei Riti, Roma, 2001. 
recibir culto en los cincuenta años posteriores a su muerte, pero quienes habían disfrutado de culto inmemorial pasaban a ser casos exceptuados y, en consecuencia, eran tratados con un procedimiento simplificado ${ }^{24}$.

Las circunstancias hicieron que Isidro fuera un santo antiguo indirectamente afectado por el ambiente de rigor creciente que rodeó el debate sobre los beatos modernos y con los que compartió las complejidades del proceso de canonización. En compensación, le favoreció el contexto de la consolidación de Madrid como capital de la monarquía española. Como veremos ahora, a sus méritos como santo natural de la Villa en la que se conservaban sus restos, logró añadir el apoyo decidido de la Corte y con él adelantar a sus ilustres compañeros de las celebraciones de 1622 .

\section{NEgOCIANDO CON LA SANTA SEDE}

Aun siendo un «santo antiguo», el desarrollo de la causa de san Isidro siguió pautas similares a las de los otros santos canonizados en 1622. Las primeras tentativas para canonizar al santo madrileño se remontaban a principios de la década de 1560, pero el proceso canónico propiamente dicho comenzó treinta años más tarde. La Santa Sede admitió su caso a trámite en 1596, tres años después de que comenzara la recogida de testimonios sobre su fama de santidad en Madrid y se enviaran las primeras cartas postulatorias. Entre 1593 y 1598, bajo la autoridad del ordinario diocesano se realizaron tres procesos informativos en la capital y algunos pueblos de la comarca, procesos que un emisario del ayuntamiento llevó a Roma inmediatamente después. La causa se paralizó en los años finales del pontificado de Clemente VIII $(+1605)$, pero fue retomada con Paulo V, contando con el apoyo de las cartas postulatorias de las principales instituciones civiles y eclesiásticas de Madrid y Castilla, y en particular -por su número e insistenciade Felipe III. Entre 1613 y 1615 se recogieron nuevos testimonios por encargo directo de la Santa Sede, que con los procesos remisoriales y compulsoriales obli-

24 Me refiero a las medidas, decisivas por constituir el eje de las canonizaciones en los siglos siguientes, conocidas como decretos de non cultum y casus exceptus para los santos que habían recibido culto inmemorial (ab inmemorabili), fijado en un mínimo de cien años. Giovanni PARISE, $I l$ «casus exceptus»: Storia e valore canonistico della confermazione pontificia di un culto prestato «ab immemorabili» ad un beato, en Periodica de Re Canonica, 105 (2016), pp. 457-474. Una síntesis general, con atención a distintos momentos históricos en Giuseppe DALLA TORRE, Processo di beatificazione e canonizzazione, en Enciclopedia del Diritto, Varese, 1987, tomo XXXVI, pp. 932-942. 
gó a comprobar la autenticidad del conjunto, de modo que pudieran ser enviados otra vez a la Congregación. En este periodo era todavía fundamental el examen de los procesos por el tribunal de la Rota, cuyos auditores preparaban un informe o relación con argumentos sobre los méritos del candidato, que incluía un dictamen final de aprobación (o no) del caso. La Relatio de la causa de Isidro comenzó a prepararse en 1616 y en ella se reconoció lo virtuoso de su vida y muerte, así como sus milagros más relevantes, sobre la base de la literatura hagiográfica y las deposiciones de los testigos. Sobre la base del informe positivo de la Rota en 1619 Paulo $\mathrm{V}$ decidió su beatificación y tres años después, sin que mediaran otros procesos o dictámenes, Gregorio XV lo canonizón ${ }^{25}$.

Dejando a un lado el estudio de los procesos ordinarios y apostólicos, que no obstante son de gran riqueza para conocer el culto floreciente del santo en la segunda mitad del siglo XVI, centraremos este apartado en el análisis de la correspondencia cruzada entre los postuladores -el ayuntamiento de Madrid y el rey, principalmente- y los agentes y embajadores que llevaron el peso de las negociaciones en la curia romana. Las más de cuarenta cartas conservadas, aunque maltratadas por el fuego, han tenido poca o nula relevancia en la mayor parte de los trabajos sobre san Isidro. Pese a lo estereotipado de las fórmulas utilizadas, una lectura detenida permite develar aspectos significativos y novedosos sobre su santificación solemne y asomarnos a los modos de negociación entre los agentes y embajadores de Madrid y los principales personajes de la curia, incluidos los auditores de la Rota, los cardenales y los mismos pontífices. También ofrecen indicios valiosos sobre el modo en que se entendió -y transformó- la relación entre la comunidad urbana y su santo patrón.

Las cartas conservadas abarcan el periodo comprendido entre 1593 y 1622 y tienen como corresponsales principalmente a los reyes de España y a sus embajadores en la Santa Sede, aunque también se incluyen algunas postulatorias o de agradecimiento dirigidas directamente al pontífice. Unas pocas proceden de las Cortes de Castilla, el Cabildo del clero y del ayuntamiento de Madrid, que también fueron interlocutores relevantes durante el proceso de canonización, especialmente esta última corporación que, a través de sus propios agentes, tomó parte en las negociaciones y corrió con todos los gastos ocasionados, como se

25 Sigo fundamentalmente la información que proporcionan Fabijan VERAJA, op. cit., pp. 57-58 y Giovanni PAPA, op. cit., pp. 37, 51, 113, 168, 243-245, 275-279, este último rico en documentación primaria poco conocida. Aparte de los procesos originales que se encuentran en el Vaticano, y de los que existe una reproducción en el archivo de la catedral de Madrid, en el Archivo de Villa de Madrid puede manejarse una copia del proceso ordinario de 1598. 
refleja en su propia correspondencia. Veamos cuales fueron los aspectos más relevantes de su contenido en las distintas fases del proceso.

Entre las cartas fechadas en la década final del siglo XVI, llama la atención la tibieza inicial del apoyo de Felipe II a la causa de Isidro, al menos en contraste con su postura en un segundo momento y con el entusiasmo de su sucesor, Felipe III. La primera misiva enviada por el rey Prudente a su embajador en Roma, el duque de Sessa, es de 1593, justo cuando comenzaron a recogerse las informaciones ordinarias. El soberano se limitó a dar curso a la instancia del ayuntamiento madrileño, que requería del pontífice el despacho de las comisiones necesarias para comenzar el proceso de canonización. Felipe II se refería al candidato como «un santo hombre llamado Isidro» y, aunque apuntaba a lo esencial de su culto -el cuerpo, la ermita y el manuscrito-, recomendaba informarse mejor de ello al embajador. Como si no se considerara parte en el caso, el rey aludía exclusivamente a «la mucha dev[oción que] esta Villa le tiene como a su natural y abogado» ${ }^{26}$. Es posible que en ese momento se sintiera más involucrado en las otras causas que apoyaba, aunque sólo tres años más tarde su nivel de compromiso con la de Isidro aumentó claramente. En otra carta a Sessa lamentaba no haber recibido respuesta y en esta ocasión no sólo remitió a las instancias del ayuntamiento y otras personas piadosas, sino también a lo mucho que deseaban su canonización «estos Reinos y yo, por la par[te y] devoción que le tengo». Además, su tono resultó especialmente firme al encargarle que pidiera al papa «que no se difiera más esto», a la vez que daba por sentado que aceptaría su decisión de nombrar al nuncio y dos o tres prelados españoles para autorizar la recogida de las informaciones y que el procedimiento se dirigiría directamente a la canonización de Isidro: «hablaréis sobre ello a Su Beatitud, diciéndole que él y otros predecesores [...] le han beatificado y le representaréis esto de mi parte y cuán digna de su santo celo será esta canoniza[ción] $\gg^{27}$.

Las negociaciones de los españoles con la Santa Sede no sólo buscaban controlar el procedimiento, sino también obtener el respaldo de las personas que dentro de la curia les serían más favorables. En su respuesta al rey, el embajador advirtió que había ciertas normas para el nombramiento de los responsables de las informaciones, pero sobre todo puso hincapié en que Clemente VIII había accedido a trasladar el caso a la Congregación de Ritos y que habían tenido la

26 Madrid, ArChivo Histórico NaCiOnal, Archivo del Ministerio de Asuntos Exteriores, Embajada de España en la Santa Sede, [en adelante AHN, AMAE, Santa Sede], legajo 21, n. 290 (25 de marzo de 1593).

27 AHN, AMAE, Santa Sede, legajo 21, n. 291 (19 de febrero de 1596). 
suerte de que ejerciera como decano el cardenal de Aragón, en ausencia de su titular, el cardenal Gesualdo; por añadidura, se libraron de tener como protonotario de la causa a Cesare Baronio -poco apreciado por su cuestionamiento de la evangelización de España por Santiago, entre otras cosas-, porque acababa de ser nombrado cardenal ${ }^{28}$. Como comprobaremos en otros casos, el favor (o desfavor) de miembros de las instituciones más relevantes se consideraba esencial para el buen fin de la canonización.

El apoyo resuelto de la corona a la causa de Isidro impulsó campañas orquestadas de postulación, muy convenientes en distintos momentos del proceso como expresión de la persistencia de sus promotores. Así, en 1596 contribuyeron con cartas el ayuntamiento, el cabildo del clero de Madrid y las Cortes de Castilla, las mismas corporaciones que respaldaron del mismo modo el envío de los procesos diocesanos a Roma en $1599^{29}$. En ese momento, los avales de la causa resultaban particularmente importantes por temor de que las tensiones entre Clemente VIII y el rey de España pudieran perjudicarla. Con el mismo tono imperativo de su padre, Felipe III encargaba entonces al duque de Sessa que hablara con el papa para que ordenase a la Congregación de Ritos hacerse cargo de las probanzas de Isidro, añadiendo la coletilla de que «siendo bastantes, como se tiene por cierto que lo serán, proceda a [su ca]nonización ${ }^{30}$. La conversación entre el embajador y el pontífice fue descrita con viveza por el licenciado Gil Jiménez, diputado de la junta de san Isidro y comisionado del ayuntamiento madrileño para el traslado de los procesos a Roma. En la carta enviada a los ediles municipales en octubre de 1599, aludía brevemente a las dificultades del embajador para tratar con el pontífice por haber «habido algunas cosas entre el rey y Su Santidad de disensiones», en referencia seguramente a los roces por el reconocimiento papal de Enrique IV de Francia o por las controversias teológicas que los reyes de España le apremiaban a resolver. El diálogo que finalmente se produjo, cuando el embajador solicitó la recogida de las informaciones del santo madrileño, fue áspero pero eficaz: al comentario sarcástico de Clemente sobre si querían canonizar a todos los santos

28 AHN, AMAE, Santa Sede, legajo 21, n. 305 (julio 1596, sin firma).

29 El primer bloque de cartas firmadas por los regidores de Madrid, el «Reino de Castilla» y el clero madrileño, el 26 de enero y 2 y 21 de marzo de 1596, respectivamente, en AHN, AMAE, Santa Sede, legajo 21, números 294, 302, 303 y 306. Las de la primavera de 1599, en los números 299 (sin firma ni fecha, pero con alusiones a «esta Villa de Madrid» y a la realización «de grandes informaciones»); 300, carta firmada, entre otros, por Francisco de Herrera de Saavedra, Domingo López de Mendoza y Rodrigo de Prado, el 15 de abril de 1599; y 301 del clero madrileño en latín.

30 AHN, AMAE, Santa Sede, legajo 21, n. 292, Felipe III a Sessa, 22 marzo 1599. 
de España, Sessa respondió tajante que «por ser tan santo [Isidro] y estar en la corte de España se había de dar lugar» ${ }^{31}$.

Según el relato de Jiménez, el pontífice aceptó remitir los procesos a la Congregación de Ritos y ordenó que se vieran, con lo que la causa del santo madrileño fue envidiada por quienes trataban de promocionar a otros candidatos. De hecho, su carta ofrece un cuadro inestimable de la intensa y competitiva carrera hacia la santidad y del modo en que eso dificultaba el progreso de Isidro en la curia. El apoyo de los cardenales y otras personas poderosas era esencial, pero los conflictos de intereses impedían avanzar:

cuando iba a hablar a algún cardenal para que intercediese por el santo estaban al parecer hablados de otros, porque luego me respondían haber muchas canonizaciones, y principalmente de frailes dominicos, que andan negociando todo lo posible por fray Luis Beltrán, y Monseñor Peña, auditor de Rota, por la santa de Portugal, y otros por otras canonizaciones, que son doce entre todas ${ }^{32}$.

En este contexto no era extraño que hubiera evitado recibirle el cardenal Rusticuccio, para quien llevaba un regalo de parte de Diego Salas Barbadillo regidor, tesorero de la cofradía de san Isidro y uno de los más activos agentes de su causa. Pero lo peor era que ni siquiera el cardenal español Guevara quisiera atender su ruego de hablar a favor de Isidro ${ }^{33}$. Con todo, es posible que la información proporcionada en su carta mostrara al ayuntamiento el camino que convenía seguir para salir con éxito en la empresa. Años más tarde, cuando la causa de Isidro entró en su recta final y el ayuntamiento madrileño decidió dar el máximo enviando como promotor Diego de Barrionuevo, éste supo cómo agasajar y regalar tanto a los poderosos en la curia y sus familiares, como a los príncipes «aficionados a la corona

31 Madrid, ARChivo De Villa, Secretaría [en adelante AVM], 2-285-2 (18 de octubre de 1599). Todas las citas que siguen proceden de este documento. Sobre el licenciado Jiménez, ver Zacarías GARCÍA VILLADA, op. cit., pp. 24 y 41. Para las disensiones de los españoles con el papado en este periodo, Paolo Broggio, Rome and the «Spanish Theology»: Spanish Monarchy, Doctrinal Controversies and the Defence of Papal Prerogatives from Clement VIII to Urban VIII, en Piers BAKER-BATES y Miles PatTenden (eds.), op. cit., pp. 85-102.

$32 \mathrm{La}$ «santa de Portugal» era la reina Isabel, canonizada en 1625. Además de ella otros siete candidatos eran de origen ibérico: Raimundo de Peñafort, Juan de Sahagún, Luis Bertrán, Ignacio de Loyola, Teresa de Jesús, Francisco Javier e Isidro Labrador. Peña advirtió a Jiménez que en la Rota no se ocuparían de otra causa hasta haber concluido la de Raimundo de Peñafort, canonizado en 1601.

33 De Fernando Niño de Guevara, apunta que «respondió un poco ásperamente y diciéndome de tantas canonizaciones». El cardenal y protonotario apostólico Jerónimo Rusticuccio simplemente envió criados a recoger las «piedras», posiblemente bezoares, que le enviaba Salas. 
de España, y con quien se debía cumplir» ${ }^{34}$. Antes de llegar a ese momento, sin embargo, hubo un paréntesis de varios años en el que el proceso resultó interrumpido o progresó a ritmo muy lento, como la correspondencia deja traslucir.

El segundo grupo de cartas destinadas a la promoción del santo madrileño en la curia romana comienza, de hecho, con un vacío de más de un lustro. Buen conocedor del tema, el hispanista francés Noël Salomon apuntó que el declive de interés estuvo relacionado con el traslado de la corte a Valladolid entre 1601 y $1606^{35}$. Poco antes de que se produjera el traslado, Felipe III hizo ya notar que «la Villa está muy desconsolada con la dilación», ${ }^{36}$ en la causa de Isidro. Aparte del valor retórico que este tipo de comentarios tenía en las cartas, la situación en Madrid no contribuía desde luego al optimismo. Junto a la obvia preocupación por los rumores de traslado de la corte, en 1599 la epidemia que azotaba buena parte de la península Ibérica había llegado a la capital. Sabedor de ello el licenciado Jiménez recomendaba a sus corresponsales en el ayuntamiento que, además de recurrir a los especialistas universales, san Roque y san Sebastián, tuvieran en cuenta a Isidro como protector: «pues que estábamos en su causa, que intercediese por su pueblo» ${ }^{37}$. Como santo por excelencia de Madrid se le invocó también para que protegiera a la villa de los prejuicios del traslado:

Isidro Santo, valga tu privanza

a aqueste pueblo tuyo, y patria tuya

y haz que esta mudanza

no mude su bien todo y la destruya ${ }^{38}$.

En una línea similar que remarcaba el vínculo especial entre el santo y la ciudad, el agente del ayuntamiento Cristóbal de Villanueva, en carta enviada des-

34 AVM, 2-285-4 «Cuenta de los gastos hechos en Roma por don Diego Barrionuevo, capitular y comisario de Madrid para la canonización de san Isidro» (1615-1623). Entre otros, menciona el regalo hecho «a cierta persona muy grave de quien tenía gran confianza Su Santidad del papa Paulo V y a quien Su Santidad había fiado la expedición del negocio de la beatificación y canonización del glorioso san Isidro, por haber mandado que le hiciese relación secreta de la verdad y justificación que tenían los procesos remisoriales y compulsoriales con cuya aprobación tuvo dicho efecto la dicha canonización, y como sabidor de que la tal persona era el juez más importante a quien se había de tener grato, buscó camino para que recibiese los regalos que se le hiciesen».

35 Nöel SALOMON, Lo villano en el teatro del Siglo de Oro, Madrid, 1985, pp. 192-193.

36 AHN, AMAE, Santa Sede, legajo 21, n. 292, Felipe III a Sessa, 22 marzo 1599.

37 AVM, 2-285-2 (18 de octubre de 1599).

38 José Fradejas Lebrero, Llanto poético al traslado de la corte en 1601, en Anales del Instituto de Estudios Madrileños, XL (2000), p. 240. 
de Roma en 1608, dejaba caer la posibilidad de que el mismo Isidro hubiera permitido la ausencia de la Corte y los daños subsiguientes por haber dejado sus miembros de perseverar en su causa de canonización. Para entonces la Corte había regresado a Madrid, pero al parecer los ediles municipales necesitaban ser galvanizados para retomar la promoción del santo local. Villanueva les instaba a compensar el silencio pasado con nuevos esfuerzos, que prometía ser fructuosos dado que el nuevo papa, Paulo V, era más favorable a los españoles que el anterior y que él mismo le servía como capellán. Les prometía influir para acelerar la causa de Isidro y situarlo por delante de los demás candidatos, si ellos conseguían cartas postulatorias de Felipe III, de cuyo interés no dudaba puesto que el santo madrileño las merecía más que otros «santos forasteros» por ser paisano del rey: «teniendo al monarca del mundo por su conterráneo» ${ }^{39}$.

En realidad, Felipe III había reiniciado ya la campaña en 1606, estimulado tal vez por la elección del nuevo papa y el retorno previsto a Madrid. El 8 de enero escribió al embajador, duque de Escalona, y al pontífice para reactivar la causa y que «se acabe la canonización del beato Isidro» ${ }^{40}$. Cabe notar que, siguiendo la política de su antecesor, el soberano consideraba que el santo madrileño era ya beato y que por eso la causa pasaría directamente a la canonización papal. Con el fin de lograrlo lo más rápidamente posible, Felipe III se convirtió desde entonces en el principal adalid de Isidro Labrador, en colaboración con un ayuntamiento revigorizado por la consolidación de la capitalidad y decidido a enviar a Roma promotores capaces y con fondos suficientes para costear los gastos que exigían la burocracia papal y las relaciones de patronazgo.

En esta fase la Villa mantuvo su papel como fuerza motriz del proceso, pero la Corte adquirió un protagonismo creciente y, en último término, decisivo. En sus cartas, Felipe III reafirmó los vínculos que le unían al santo no sólo por su devoción personal, sino también por ser ambos hijos de una misma tierra, que, además, era la sede de la corte real. El soberano pasó de referirse a Isidro como «natural de aquel lugar» a recalcar que el cuerpo del santo estaba en su Corte y era muy venerado en ella. Cuando escribía al embajador conde de Castro en

39 AVM, Secre. 2-285-3 (2 de septiembre de 1608). Incluye otras cartas suyas hasta que dejó Roma en 1612. En la 15 de octubre de 1610 aseguraba el avance de la causa de Isidro cuando los auditores de la Rota concluyeran el examen de la de Carlo Borromeo, canonizado ese mismo año. Cristóbal Villanueva es citado en Pares como doctor y clérigo de Badajoz, procurador en Roma del duque de Béjar y capellán pontificio. En la carta de 1608 aludía al salario que el ayuntamiento le pagaba para pedir un aumento.

40 AHN, AMAE, Santa Sede, legajo 21, n. 307 y 308. 
1610, apuntaba como de costumbre lo mucho que el ayuntamiento deseaba verle canonizado, pero también que él escribía al pontífice «[por la devoci]ón que yo tengo a este glorioso santo y ser natural de Madrid, donde yo n[ací, y...] que de ordinario reside mi corte en aquella Villa ${ }^{41}$.

La consideración de Isidro como santo no sólo de la Villa, sino también de la Corte explica que Felipe III enviara a Roma una docena de cartas relacionadas con la canonización de Isidro en la última década de su reinado. Solicitó el apoyo de los cardenales españoles, Antonio Zapata y Gaspar de Borja, este último embajador en la Santa Sede entre 1616 y 1619, del mismo modo que recomendaba ganarse al cardenal Scipione Borghese, sobrino del papa, y a «los cardenales a quienes está cometido el negocio» ${ }^{42}$. Envió cartas postulatorias para el papa a cada uno de sus nuevos embajador -se sucedieron varios hasta que en 1619 ocupó el cargo el duque de Alburquerque-, encargándoles encarecidamente que hicieran lo posible para obtener la pronta canonización del santo. Entre otras cosas, les pedía colaboración con el procurador del ayuntamiento Diego de Barrionuevo, «llevándolo a besar el pie a su Beatitud y [dan]dole a conocer a la personas con quien hubiere de negociar ${ }^{43}$. Desde Madrid se siguieron de cerca los avances en el procedimiento, como indican las muestras de satisfacción del soberano, cuando en 1616 Paulo V mandó a los jueces de la Rota examinar los procesos apostólicos recién completados; dos años más tarde se congratulaba de que la relación de ese tribunal hubiera concluido de forma positiva y la causa devuelta a la Congregación de Ritos, de modo que, como señalaba a su embajador, la parte burocrática había finalizado y «lo que queda ahora es meramente de gracia $\gg^{44}$.

Efectivamente, la gracia papal se alcanzó enseguida, pero no en forma de canonización, como se esperaba en la corte española, sino de beatificación. El resultado tuvo que parecer como mínimo chocante, no sólo porque se diera por descontado que Isidro ya disfrutaba de reconocimiento de la santidad al modo antiguo, sino también porque tampoco era previsible que todos los candidatos

41 AHN, AMAE, Santa Sede, legajo 21, n. 311 (20 de marzo de 1610). La otra carta citada es la de la nota anterior a Paulo V y para otros ejemplos del nuevo énfasis en la «Corte», n. 309 (Felipe III a Aytona, septiembre 1608) y 310 (Felipe III al conde de Castro, 9 de abril 1615).

42 AHN, AMAE, Santa Sede, legajo 21, n. 329 (Felipe III al cardenal Borja, 24 de mayo de 1618), aunque ya se refiere al «cardenal Burguesio» en n. 310 (Felipe III 9 de abril 1615) y lo hará varias veces más tarde, pues, como veremos, las negociaciones con él resultaron fundamentales.

43 AHN, AMAE, Santa Sede, legajo 21, n. 310 (Felipe III al don Francisco de Castro, duque de Tauristano, 9 de abril 1615) y n. 328 (Felipe III al cardenal Borja, 2 de mayo de 1616).

44 AHN, AMAE, Santa Sede, legajo 21, n. 329 (Felipe III al cardenal Borja, 24 de mayo de 1618). 
pasaran por la beatificación como paso previo a la canonización. No hacía ni siquiera diez años desde que ese procedimiento comenzara a utilizarse de forma sistemática -Carlo Borromeo fue el último en ser directamente canonizado en 1610-, como un mecanismo para satisfacer la demanda creciente y evitar medidas definitivas demasiado apresuradas. Es cierto que el breve de beatificación de san Isidro fue generoso pues, además de establecer que en Madrid se le rindieran los honores litúrgicos propios de un santo patrón, permitió su culto en España y sus posesiones de ultramar ${ }^{45}$. Sin embargo, puesto que los gobernantes españoles habían trabajado para conseguir una declaración universal y definitiva de la santidad del Labrador, el logro alcanzado en mayo de 1619 tuvo que resultar decepcionante.

La correspondencia diplomática no dejó, sin embargo, traslucir señales de desaliento, sino que expresó más bien la voluntad de seguir trabajando para que el asunto culminara lo más rápido posible. Aunque en la curia les habían dado a entender que «no habría novedad por a[hora]», a Madrid llegó el aviso de que algunos cardenales insinuaron al procurador Barrionuevo que, si seguía solicitando la canonización de Isidro, «se saldría con ella» ${ }^{46}$. La urgencia en la corte española había, además, aumentado desde el otoño de 1619 porque se atribuyó a la intercesión del nuevo beato la curación de Felipe III, postrado por una grave enfermedad cuando regresaba de la jornada de Portugal. En una ceremonia extraordinaria, el cuerpo incorrupto del santo había sido llevado hasta Casarrubios, situado a unos cincuenta kilómetros de Madrid, y así el rey pudo verlo, tocarlo y rogar directamente su curación. El agradecimiento y deseo de reciprocidad se añadió entonces a los argumentos utilizados por Felipe III en la media docena de cartas que envió a Roma en 1620. En una dirigida al duque de Alburquerque desde Aranjuez subrayaba la importancia de convencer a $\ll$ Su Santidad para que acabe de perfeccionar esta obra, y pong[a al bien]aventurado en el lugar que merece» ${ }^{47}$. Temeroso de que la insistencia pudiera molestar al pontífice, recomendaba esperar a la mejor ocasión y hablarle con «maña», como él mismo hacía en las cartas que le enviaba; con tono amable, el monarca

45 El decreto de beatificación de 14 de junio de 1619 en AVM, 2-285-6.

46 AHN, AMAE, Santa Sede, legajo 21, n. 312. El año de este documento no es legible por su mal estado, pero por su contenido tuvo que ser de las primeras enviadas al nuevo embajador y Alburquerque lo fue entre 1619 y 1623 . Como la carta está fechada un 21 de diciembre, me inclino a pensar que se escribió en 1619.

47 AHN, AMAE, Santa Sede, legajo 21, n. 317. Una copia de la carta de Felipe III al papa en n. 325 y otra al cardenal Borghese, de 5 mayo de 1620, en n. 325bis. 
planteaba ahora el caso como una concesión personal, subrayando «el consuelo y gusto que recibiré con gracia ta[n] singular» ${ }^{48}$.

En octubre de 1620, Alburquerque envió un despacho urgente para comunicar que el papa había tomado la decisión de canonizar a san Isidro. No entró en detalles sobre si la rapidez se debía a que se utilizó el informe previo de la Rota, pero sí destacó la ayuda decisiva del cardenal Borghese. Con más detalle, una consulta real al Consejo de Estado de noviembre de ese año revela que resultó crucial la concesión de algunas mercedes para los familiares del pontífice. Estos habían solicitado el tratamiento de grande de España para el príncipe de Sulmona, otro de los sobrinos de Paulo V, y, a pesar de que semejante privilegio raras veces se ponía al alcance de nobles italianos, en esas circunstancias no pareció aconsejable rehusar la petición. Los consejeros de Felipe III recomendaron que la merced se diera a conocer con prudencia para que no dijeran los malintencionados que «canoniza el Papa un santo porque Vuestra Majestad hace grande a un sobrino suyo». Baltasar de Zúñiga, además, propuso recriminar al embajador por haber bromeado con un asunto tan serio, al aconsejar «que será muy conforme a la grandeza de Vuestra Majestad que también le canonice a su sobrino» ${ }^{49}$.

El último grupo de cartas se ocupa fundamentalmente de la organización de la ceremonia de proclamación de san Isidro. Se conservan siete misivas enviadas por Felipe IV a su embajador en la Santa Sede y al nuevo pontífice entre 1621 y 1622. Gregorio XV asumió el compromiso de su antecesor con el santo madrileño, pero dio un giro inesperado al asunto cuando decidió canonizar también a otros cuatro candidatos. Las negociaciones desde Madrid se encaminaron entonces a disponer lo más conveniente para la proclamación de los santos españoles. Tras congratularse por la buena noticia, Felipe IV supuso que la Compañía de Jesús querría celebrar a san Ignacio de Loyola y san Francisco Javier en una misma ceremonia y, en consecuencia, encargó al duque de Alburquerque que hiciera lo posible para que «la Santa Teresa de Jesús sea canonizada en compañía del glorioso [Isidro], pues con esto se abreviará más y será menos la costa ${ }^{50}$. Para

48 AHN, AMAE, Santa Sede, legajo 21, n. 316 (Felipe III a Alburquerque, 8 de junio de 1620) y 315 (Felipe III a Paulo V, 20 de agosto de 1620).

49 Simancas, ArChivo General, Estado, leg. 2994. Despacho del embajador y consulta del inquisidor general y el Comendador Mayor de León, Baltasar de Zúñiga, 13 y 14 de noviembre de 1620.

50 AHN, AMAE, Santa Sede, legajo 21, n. 322 (Felipe IV a Alburquerque, 1621, ilegible el mes, aunque visible el lugar, Valsaín). Esa carta es, de todos modos, posterior a otra en la que acusa recibo de la noticia de canonizar a los dos santos jesuitas, n. 319 (Felipe IV a Alburquerque, 20 de julio [1621]). 
asegurarse de ello, el primero de noviembre de 1621, escribió directamente al pontífice, haciéndole saber su preferencia:

holgaré de que en caso que la declaración de la canonización de los cuatro santos, que ahora ha de hacer Vuestra Beatitud, no pueda ser de todos juntos, sino de dos en dos, se canonice la santa madre Teresa de Jesús en compañía del glorioso san Isidro, por el gran consuelo y satisfacción que de ello resultará a todos estos reinos $^{51}$.

La respuesta inicial resultó ambigua, pues, según el embajador, Gregorio XV se había mostrado favorable a la idea, pero se temía que no acabara secundándola. En efecto, a pesar de que el rey continuó insistiendo hasta dos meses antes de la celebración, al fin tuvo que someterse a la resolución papal de canonizar a todos los santos de una vez. Ante los hechos consumados, no tuvo más alternativa que seguir el consejo de su embajador y dar gracias al papa por haber decidido «canonizar, juntamente con el glorioso san Isidro y la santa Teresa de Jesús, los otros dos santos españoles» ${ }^{52}$.

La falta de acuerdo sobre la ceremonia fue quizás resultado de la falta de precedentes. Alguna vez se habían canonizado dos santos al mismo tiempo, pero nunca cinco. Es fácil entender que Felipe IV y sus consejeros contemplaran el reparto de los cuatro españoles por parejas -lo que se hiciera con Filippo Neri no parecía asunto suyo-. La asociación de san Isidro con santa Teresa es razonable, si consideramos que los otros españoles eran jesuitas y la Compañía solía convertir las celebraciones en exaltación de su propia identidad ${ }^{53}$. Puesto que los jesuitas estaban bajo obediencia directa del pontífice y otras monarquías europeas habían colaborado en la promoción de Ignacio y Francisco Javier, cabía pensar que en una ceremonia compartida como mínimo se difuminaría el mensaje que los otros santos eran susceptibles de vehicular. Como patrón de la Villa y Corte, Isidro Labrador celebraba a la capital de la monarquía y al mismo tiempo a su soberano -recordemos el cuadro de la curación de Felipe III que presidió la ceremonia-. El

51 AHN, AMAE, Santa Sede, legajo 21, n. 321 (Felipe IV a Gregorio XV, 1 de noviembre de 1621).

52 AHN, AMAE, Santa Sede, legajo 21, n. 330 (Felipe IV a Gregorio XIII, en mal estado pero 1622); ver también n. 323 (Felipe IV a Alburquerque, 22 de enero de 1622, n. 326 Felipe IV a Alburquerque, febrero de 1622) y, después de las celebraciones, n. 331 (Felipe IV a Alburquerque, 4 de mayo 1622).

53 José Luis BETRÁN (ed.), La Compañía de Jesús y su proyección mediática en el mundo bispánico durante la Edad Moderna, Madrid, 2010, especialmente la presentación del volumen y el capítulo final de Eliseo SERrano MARTín, Annus mirabilis. Fiestas en el mundo por la canonización de los jesuitas Ignacio y Francisco favier en 1622, pp. 297-343. 
enaltecimiento de la monarquía española no quedaba perjudicado compartiendo la ocasión con Teresa de Jesús, porque unos años antes la reformadora del Carmelo había sido propuesta como copatrona de España, junto al apóstol Santiago, y confiaba en confirmarla apenas estuviera canonizada. A pesar de que los defensores del patronato único de Santiago se opusieran rotundamente a ella, Felipe IV y su valido Olivares apoyaban con entusiasmo a la santa. Vincular a Teresa a un «santo antiguo» como Isidro podía reforzar su posición, pues una proclamación de ambos celebraría a la nueva patrona de la monarquía española junto con el patrón de su capital. Tampoco era del todo nuevo que el Labrador se asociara con el patronazgo de España, algo que Lope de Vega había apuntado en su poema de 1599: «Mira patria, qué patrón/ en Isidro España tiene ${ }^{54}$. Los carmelitas descalzos de Madrid sancionaron la propuesta en los festejos de la capital, colocando en su altar sendas imágenes de los dos santos guiando la nave de la Iglesia contra la Herejía, como si ambos encarnaran a la monarquía española. Sin embargo, en las celebraciones de Roma, solamente Isidro pudo representarla en la proclamación y, al día siguiente, en la procesión con los estandartes de los cinco santos; cada uno fue llevado a la iglesia de la orden religiosa correspondiente, salvo el del santo madrileño, que se recogió en la emblemática iglesia de Santiago de los españoles ${ }^{55}$.

Lo que Gregorio XV pretendía al canonizar a Isidro con otros cuatro santos de mayor renombre en una ceremonia que priorizaba al santo madrileño no es fácil de explicar con la documentación manejada. Pudo haber sido un modo de evitar conflictos ceremoniales entre la diversidad de promotores o una fórmula para ahorrar gastos y esfuerzos. Pero también es posible que se tratara de un gesto de afirmación de la supremacía papal en materia de canonizaciones. La correspondencia diplomática española deja entrever el modo sutil, pero firme, con que las pretensiones del rey de España fueron frenadas en Roma. Clemente VIII y Paulo V hicieron caso omiso de la presunción española de que Isidro ya era beato por haber sido canonizado al modo antiguo y merecía, por tanto, pasar directamente a la fase final del proceso. La decisión de Gregorio XVI sobre la

54 LOPE DE VEGA, Isidro, f. 227r. En su Relación de las fiestas (...) en la canonización, sin paginar describe la nave de los carmelitas en las fiestas de Madrid. Sobre el controvertido copatronazgo de santa Teresa, Erin K. RowE, Saint and Nation: Santiago, Teresa of Avila, and Plural Identities in Early Modern Spain, University Park, 2011.

55 Dandelet, op. cit., pp. 197-198 y Copeland, op. cit., pp. 111-112. En este último trabajo se indica, sin embargo, que el duque de Alba no estuvo contento con la posibilidad de emparejar a santa Teresa y san Isidro, aduciendo que los méritos de aquélla eran mayores. 
proclamación conjunta dejaba meridianamente claro que decidir cuándo y cómo se canonizaba a uno o más santos no estaba en las manos del rey de España, sino en las del pontífice exclusivamente.

La capacidad de la curia para otorgar un significado propio a los candidatos a la canonización tampoco se debe infravalorar. El santo de Madrid que la Rota aprobó en su dictamen no era precisamente una expresión gloriosa de la monarquía hispana. En las palabras introductorias dirigidas al papa, se presentaba así:

Hoy ofrecemos a Vuestra Santidad para su inclusión en la categoría de los santos no a un rey coronado con una diadema, no a un príncipe o alguien rico en joyas y resplandeciente de oro. De hecho, de esa manera, el culto es poco adecuado para imitar la pobreza y humildad de Cristo, como el emperador Heraclio demostró suficientemente con su ejemplo. Tampoco presentamos a un hombre que viste con molicie, a quien con tal vestimenta, hinchado de lujo, cargado e impregnado de aceite perfumado, se presenta a la admiración de los hombres y vive en un palacio real ${ }^{56}$.

Una interpretación extrema de estas palabras las consideraría una crítica a la vanidad y arrogancia de los cortesanos españoles, bien conocidos en la Europa de la época por sus vestidos, modales, y perfumes. Sin llegar tan lejos, no cabe duda de que presentaban a un santo opuesto al estereotipo del cortesano, a un labrador humilde, modelo de reyes y grandes - «superior a ricos y príncipes de la Tierra $\gg-57$.

Esta característica inversión cristiana del humilde sobre el poderoso, del pobre sobre el rico tuvo un notable impacto en el largo recorrido del culto de san Isidro hasta hoy. Por mucho que en el siglo XVII se le intentara convertir en «Labrador Cortesano», su papel como patrón de la Corte no llegó a cuajar ${ }^{58}$. El espacio urbano prioritariamente asociado con el santo fue aquel en el que la tradición situaba su labranza y donde estaba la fuente milagrosa y la ermita. En

56 BNE, ms. 8408 Smo. D.N. Paulo Papae V. Hispaniarum Canonizationis. Servi Dei Isidori Agricolae Oppidi de Madrid. Relatio per tres Rotae Auditores ab eadem S.V. deputatos nempe. Francisco Sacratum, Archiepum. Damascenus, Baptistam Coccinum, decanum eiusdem Rotae. Alphonsus Mançanedum de Quiñones, f. 1r. «Offerimus hodie S.V. in Sanctos numero adscribendum non Regum Diademate coronatum, non Principem, aut divitem aliquem gemmis auroque fulgentem, et pauperitatem satis suo exemplo ostendit Heraclius Imperator. Non etiam adducimus hominem mollibus indutum qui enim hac veste, luxuque turgidi, et unguentis oppleti ac delibuti se hominibus admirandos praestant in domibus Regum habitant».

57 Ibid. «Divites et Principes terrae antecellere mereatur».

58 Gregorio DE ARGAYZ, La soledad y el campo laureados por el solitario de Roma y el labrador de Madrid, San Benito y San Isidro, Madrid, 1671, p. 121.

\section{0}


la misma línea, el culto de san Isidro se extendió por numerosas localidades agrícolas en España, el sur de Italia y América, a menudo conviviendo y absorbiendo el culto a otros santos campesinos ${ }^{59}$. Aunque su canonización le convirtió en un santo universal, Isidro no ha dejado de ser un santo estrechamente ligado a la tierra, un ejemplo magnífico de la pervivencia de la religión local en la Iglesia de la Contrarreforma.

\section{REFERENCIAS BIBLIOGRÁFICAS}

\section{a) Fuentes}

ARCHIVO DE VILla, MADRID, Libro de Acuerdos de 1652, 1653 y 1588.

- Secretaría 2-285-1 a 2-85-6

ARChivo Histórico Nacional, MADrid, Archivo del Ministerio de Asuntos Exteriores, Embajada de España en la Santa Sede, leg. 21, n. 290, 291, 292, 294, 299, 300, 301, 302, 303, $305,306,307,308,309,310,311,312,313,314,315,316,317,318,320,321,322,323$, 325, 325bis, 326, 328, 329, 330, 331 .

ARCHIVo GENERAL DE SimanCAS, Estado, leg. 2994.

Biblioteca Nacional, Madrid, Ms. 8408 Smo. D.N. Paulo Papae V. Hispaniarum Canonizationis. Servi Dei Isidori Agricolae Oppidi de Madrid. Relatio per tres Rotae Auditores ab eadem S.V. deputatos nempe. Francisco Sacratum, Archiepum. Damascenus, Baptistam Coccinum, decanum eiusdem Rotae. Alphonsus Mançanedum de Quiñones (44 hojas).

— Ms. 17649 Historia Sancti Isidori Agricolae ac beatae Mariae de la Cabeza unicae eius uxoris madritensium toletanae dioecesis.

- VE 201-117 Relación en suma sacada de la información que se ba becho de la vida y milagros de S. Isidro, labrador en la Villa de Madrid [1598] (11 hojas).

b) Bibliografía

ANSELMI, Alessandra, Roma celebra la monarchia spagnola: il teatro per la canonizazione di Isidoro Agricola, Ignazio di Loyola, Francesco Saverio, Teresa di Gesù e Filippo Neri (1622), en José Luís COlOMER (ed.), Arte y diplomacia de la Monarquía Hispánica en el siglo XVIII, Madrid, 2003, pp. 221-246.

59 SAlOMON, op. cit, pp. 188-189. G. FreIWALD-KoRTH, San Isidro Labrador und santa María de la Cabeza. Ibre Ikonographie in Spanien bis zum Ende des 18 Jabrhumderts, Hamburgo, 1981. María Assumpta ROIG TORRENTÓ, Coexistencia de primeras advocaciones a santos locales con la nueva devoción a San Isidro Labrador (XVII-XVIII), en Boletín del Museo e Instituto Camón Aznar, XXXIII (1988), pp. 81-102. 
ANTIDST, Vicente Justiniano, Verdadera relación de la vida y muerte del padre fray Luis Bertrán, de bienaventurada memoria, Zaragoza, 1583.

ARGAYZ, Gregorio de, La soledad y el campo laureados por el solitario de Roma y el labrador de Madrid, San Benito y San Isidro, Madrid, 1671.

BeníteZ SÁNCHEZ-Blanco, Rafael (ed.), Tríptico de la expulsión de los moriscos. El triunfo de la razón de estado, Montpellier, 2012.

BLEDA, Jaime, Vida y milagros del glorioso San Isidro el Labrador, bijo, abogado y patrón de la Real Villa de Madrid, Madrid, 1622.

Broggio, Paolo, Rome and the «Spanish Theology»: Spanish Monarchy, Doctrinal Controversies and the Defence of Papal Prerogatives from Clement VIII to Urban VIII, en Piers BAKER-BATES y Miles PatTEnden (eds.), The Spanish Presence in Sixteenth-Century Italy: Images of Iberia, Farnham, 2015, pp. 85-102.

BURKE, Peter, The historical anthropology of early modern Italy. Essays on perception and communication, Cambridge, 1987.

Christian, William, Religiosidad local en la España de Felipe II, San Sebastián, 1991.

COPELAND, Clare, Spanish Saints in Counter-Reformation Italy, en Piers BAKER-BATES y Miles Pattenden (eds.), The Spanish Presence in Sixteenth-Century Italy: Images of Iberia, Farnham, 2015, pp. 102-123.

Dalla TORRE, Giuseppe, Processo di beatificazione e canonizzazione, en Enciclopedia del Diritto, Varese, 1987, tomo 36, pp. 932-942.

DANDELET, Thomas, «Celestiali eroi» e lo «splendor d'Iberia». La canonizzazione dei santi spagnoli a Roma in età moderna, en Giovanna FIUME (ed.), Il santo patrono e la città. San Benedetto il Moro: culti, devozioni, strategie di età moderna, Venecia, 2000, pp. 183-198.

DÁvILA Y TOLEDO, Sancho, De la veneración que se debe a los cuerpos de los santos y a sus reliquias, Madrid, 1611.

DitCHFIELD, Simon, Liturgy, Sanctity and History in Tridentine Italy: Pietro Maria Campi and the preservation of the particular, Cambridge, 1995.

- Il mondo della Riforma e della Controriforma, en AA.VV., Storia della santità nel cristianesimo occidentale, Roma, 2005, pp. 261-329.

- Coping with the «beati moderni»: Canonization procedure in the aftermath of the Council of Trent, en Thomas M. MCCOOG (ed.), Ite inflammate omnia. Selected historical papers from conferences beld at Loyola and Rome in 2006, Roma, 2010, pp. 413-439.

FERNÁNDEZ MONTES, Matilde, San Isidro, de labrador medieval a patrón renacentista y barroco de la Villa y Corte, en Revista de dialectología y tradiciones populares, tomo LVI (2001), pp. 41-95.

FITA, Fidel, Madrid desde el año 1235 hasta el de 1275. Ilustraciones y texto de la Vida de San Isidro por Juan Diácono, en Boletín de la Real Academia de la Historia, IX (1886), pp. 11-157.

FREIWALD-KORTH, Gabriele, San Isidro Labrador und santa María de la Cabeza. Ibre Ikonographie in Spanien bis zum Ende des 18 Jabrbumderts, Hamburgo, 1981.

GARCÍA VILlaDA, Zacarías, San Isidro labrador en la bistoria y en la literatura, Madrid, 1922.

GOTOR, Miguel, I beati del Papa. Santità, Inquisizione e obbedienza in età moderna, Florencia, 2002.

- Le canonizzazioni dei santi spagnoli nella Roma barocca, en Carlos HERNIANDO (coord.), Roma y España, un crisol de la cultura europea en la Edad Moderna, Madrid, 2007, tomo 2, pp. 621-639.

HARRIS, Katie, «A known boly body, with an inscription and a name»: Bishop Sancho Dávila y Toledo and the Creation of St. Vitalis, en Archiv für Reformationsgeschichte, 104 (2013), pp. 245-271. 
LOPE DE VEGA, Comedia famosa de san Isidro Labrador de Madrid, en Obras de Lope de Vega, tomo 10, Comedias de vidas de santos, Biblioteca de Autores Españoles, tomo 178, Madrid, 1965.

- Isidro. Poema castellano, Madrid, 1599.

- Relación de las fiestas que la insigne Villa de Madrid hizo en la canonización de su bienaventurado bijo, y patrón San Isidro, Madrid, 1622.

LÓPEZ DE HOYOS, Juan, Historia y relación verdadera de la enfermedad, felicísimo tránsito y suntuosas exequias fúnebres de la serenísima reina de España doña Isabel de Valois, Madrid, 1569.

MARCHAmalo SÁnCHEZ, Antonio, La Iglesia Magistral de Alcalá de Henares en la universidad cisneriana, 1499-1831, tesis doctoral, Universidad Complutense de Madrid, 2017.

MARIETA, Juan de, Historia eclesiástica de todos los santos de España, Cuenca, 1596.

OLDS, Katrina B., Forging the Past. Invented Histories in Counter-Reformation Spain, New Haven-Londres, 2015.

PAPA, Giovanni, Le cause di canonizzazione nel primo periodo della Congregazione dei Riti, Roma 2001.

PARISE, Giovanni, Il «casus exceptus»: Storia e valore canonistico della confermazione pontificia di un culto prestato «ab immemorabili» ad un beato, en Periodica de Re Canonica, 105 (2016), pp. 457-474.

Río BARREDO, María José del, Literatura y ritual en la creación de una identidad urbana: Isidro, patrón de Madrid, Edad de Oro, XVII (1998), pp. 149-168.

- Madrid, Urbs Regia. La capital ceremonial de la monarquía católica, Madrid, 2000.

RoIG TorRentó, María Assumpta, Coexistencia de primeras advocaciones a santos locales con la nueva devoción a San Isidro Labrador (XVII-XVIII), en Boletín del Museo e Instituto Camón Aznar, XXXIII (1988), pp. 81-102.

RowE, Erin K., Saint and Nation: Santiago, Teresa of Avila, and Plural Identities in Early Modern Spain, University Park, 2011.

SALOMON, Noël, Lo villano en el teatro del Siglo de Oro, Madrid, 1985.

SANCTORO, Joan Basilio, Segundo volumen de la hagiografía y vidas de los santos del NuevoTestamento, Bilbao, 1580.

SERrano MarTín, Eliseo, Santidad y patronazgo en el mundo hispánico de la Edad Moderna, en Studia Historica, Historia Moderna, 40/1 (2018), pp. 75-123.

SERRANO Y SANZ, Manuel, Memorial de fr. Jaime Bleda, en que expone sus servicios y solicita se le conceda una pensión, en Revista de Archivos, Bibliotecas y Museos de Madrid, IV (1900), pp. 275 276.

VAUCHEZ, André, La sainteté en Occident aux derniers siècles du Moyen-Age, Roma, 1988.

VERAJA, Fabijan, La beatificazione. Storia, problemi, prospettive, Roma, 1983.

Villalon, Andrew, San Diego de Alcala and the Politics of Saint-Making in Counter-Reformation Europe, en The Catholic Historical Review, 83/4 (1997), pp. 691-715.

VILlEGAS, Alonso de, Vida de Isidro Labrador, Madrid, 1592.

VisCEglia, María Antonietta, Roma papale e Spagna. Diplomatici, nobili e religiosi tra due corti, Roma, 2010.

ZOZAYA MONTES, Leonor, Pesquisas documentales para narrar la bistoria de San Isidro. Gestiones para una canonización iniciada en 1562, en Prisma social, 4 (junio 2010), pp. 2-35. 
0000 